\title{
Millennials and Reduced Car Ownership: Evidence from Recent Transport Surveys
}

\author{
Peng Chen ${ }^{1} \mathbb{O}$, Haoyun Wang ${ }^{2}$ \\ ${ }^{1}$ School of Public Affairs, University of South Florida, 2 Edward J. Bloustein School of Planning and Public Policy, Rutgers University \\ Keywords: millennials, attitudinal factors, car reduction, car ownership, heckman selection model, san francisco bay area
}

Transport Findings

\begin{abstract}
This study examines the likelihood millennials are to own a car and the factors that have driven a reduction in car consumption. Based on a travel decision survey performed in 2015 in San Francisco, no significant evidence supports the claim that millennials are different from prior generations in terms of car ownership. Individuals with higher incomes and those that preferred more access and convenience were more likely to own a vehicle.
\end{abstract}

\section{HYPOTHESES}

Anecdotal reports continually indicate that millennials (born between 1983 and 2000) travel and behave differently than prior generations at similar stages in life. They generally avoid cars, delay when they get a driver's license, and favor multimodal transport, urban life, and emerging technologies (Delbosc and Ralph 2017; McDonald 2015; Circella et al. 2017). Their trips are often of shorter distance, and they use alternative modes of transport more frequently. However, these existing studies have been mostly descriptive, lacking statistical examination. Their conclusions were summarized based on data collected just after the economic recession. This information supports the narrative that millennials own cars less frequently due to the economic environment at the time.

Although car ownership decreased in the US for a period after the 2008 economic recession, as the economy gradually recovered, car ownership increased as well (Sivak 2018). An alternative hypothesis is that millennials still wanted to own cars, but were unable to afford them following the recession. In general, this examination of millennial consumption patterns requires evidence based on statistics.

Furthermore, most existing studies were implemented on a macro level by examining census groups and counties, while neglecting individuals themselves. Research conducted on an individual level can account for the selfselection effect of car ownership, and provide additional insight.

\section{RESEARCH QUESTIONS}

Therefore, this study seeks to answer the following questions:

- Are millennials significantly different from prior generations in terms of car reduction and car ownership?

- What attitudinal factors can explain a reduction in car ownership? 


\section{DATA}

The study area was the San Francisco (SF) Bay Area, which is a large metropolitan region with a well-functioning multimodal transport system. This study employed a travel decision survey from 2015, which was collected by the SF Municipal Transportation Agency. This survey was conducted within the city and county of SF as well as the eight surrounding counties. They received a total of 762 responses.

\section{METHODS}

This study employed two models, a Heckman selection model and a binary logit model, to examine car reduction and car ownership. For car reduction, one statistical concern for sample selection arose due to the partial observability of the variable of interest. More specifically, only respondents who had stopped using cars during the past three years would report their reasons for car reduction. Heckman $(1977 ; 1976)$ proposed a simple solution that treated the selection problem as an omitted variable problem, and this method was utilized to address this selection bias. An additional explanatory variable used to correct for self-selection in the Heckman selection model was trip frequency. In the binary logit model, the objective variable was car ownership, indicating if respondents had cars or not (Agresti 2003).

When processing the data, observations with missing values were dropped. The final sample had 325 observations, and only 63 stated reasons for car reduction. To adjust for the self-selection effect, this study included two groups of selfreported attitudinal factors. Individuals reduced car usage for various reasons, like, parking unavailability and costs, car ownership-related costs, infrequent use, physical constraints, life events, and car unavailability. Individuals ranked their driving priorities of improved mobility, easy access to multiple destinations, traveling with children or carrying something, and inexpensive or free parking.

\section{FINDINGS}

Table 1 shows a descriptive analysis of the selected variables. It is worth mentioning that about $81 \%$ of the respondents owned cars, and about $17 \%$ of the respondents reduced the number of cars they owned during the past three years.

Table 2 shows the modeling outcome for car reduction, in which only two variables were significant. Asians were unlikely to reduce the number of cars owned. People who cared about their speed, which is related to mobility and travel time, were unlikely to reduce the number of cars owned. Although people stated various reasons for car reduction, none of these attitudinal factors were significant. The multiple $\mathrm{R}^{2}$ value was 0.05 , indicating that the explanatory variables did not relate strongly to the variations in trip frequency. The p-value on the Inverse Mills Ratio was large. The null hypothesis that errors in the two-stages estimation are uncorrelated cannot be rejected. 
Table 1: Variable Description and Data Summary

\begin{tabular}{|c|c|c|c|c|c|c|c|}
\hline $\begin{array}{l}\text { Continuous } \\
\text { Variable }\end{array}$ & Description & Mean & S.D. & Min & Max & Percent & $\begin{array}{r}\text { Sample } \\
\text { Size }\end{array}$ \\
\hline $\begin{array}{l}\text { Trip } \\
\text { Frequency }\end{array}$ & $\begin{array}{l}\text { The number of trips during a day, in } \\
\text { count }\end{array}$ & 4.74 & 3.31 & 1.00 & 18.00 & & 569 \\
\hline Income & Individual annual income, in $\mathrm{K} \$$ & 77.5 & 85.39 & 0.00 & 250.00 & & 597 \\
\hline \multicolumn{8}{|c|}{ Discrete Variable } \\
\hline $\begin{array}{l}\text { Car } \\
\text { Owned* }\end{array}$ & \multicolumn{5}{|l|}{ If the respondent owns a car 1 ; else 0} & $81.10 \%$ & 762 \\
\hline $\begin{array}{l}\text { Car } \\
\text { Reduced* }\end{array}$ & \multicolumn{5}{|c|}{ If the respondent had a car reduced during the past three years 1 ; else 0} & $16.67 \%$ & 762 \\
\hline Millennial* & \multicolumn{5}{|c|}{ If the respondent is aged 18 to 34,1 ; else 0} & $26.96 \%$ & 738 \\
\hline Gender & \multicolumn{5}{|l|}{ If the respondent is a male, 1 ; else 0} & $54.46 \%$ & 762 \\
\hline White* & \multicolumn{5}{|c|}{ If the respondent's race is white, 1 ; else 0} & $52.65 \%$ & 718 \\
\hline Asian* & \multicolumn{5}{|c|}{ If the respondent's race is Asian, 1 ; else 0} & $24.93 \%$ & 718 \\
\hline In/Out SF* & \multicolumn{5}{|c|}{ If the respondent lives in San Francisco County, 1; other counties in SF Bay Area 0} & $50.13 \%$ & 762 \\
\hline Speed* & \multicolumn{5}{|c|}{$\begin{array}{l}\text { If the respondent's stated reason for driving is faster access when compared with } \\
\text { alternative modes, } 1 \text {; else } 0\end{array}$} & $77.28 \%$ & 471 \\
\hline Trip Chain* & \multicolumn{5}{|c|}{$\begin{array}{l}\text { If the respondent's stated reason for driving is that he/she has multiple stops during a } \\
\text { trip, } 1 \text {; else } 0\end{array}$} & $40.34 \%$ & 471 \\
\hline Load* $^{*}$ & \multicolumn{5}{|c|}{$\begin{array}{l}\text { If the respondent's stated reason for driving is that he/she carries something or travels } \\
\text { with children, } 1 \text {; else } 0\end{array}$} & $63.38 \%$ & 471 \\
\hline \multirow{5}{*}{ TNCUse } & \multicolumn{5}{|l|}{ If the respondent does not use TNCs, 1} & $59.19 \%$ & 762 \\
\hline & \multicolumn{5}{|l|}{ If the respondent rarely uses TNCs, 2} & $20.34 \%$ & 762 \\
\hline & \multicolumn{5}{|l|}{ If the respondent uses TNCs monthly, 3; } & $8.53 \%$ & 762 \\
\hline & \multicolumn{5}{|l|}{ If the respondent uses TNCs weekly, 4; } & $10.24 \%$ & 762 \\
\hline & \multicolumn{5}{|l|}{ If the respondent uses TNCs daily, 5} & $1.71 \%$ & 762 \\
\hline \multicolumn{8}{|c|}{ Sample Selection Variable (reasons for car reduction during the past three years) } \\
\hline $\begin{array}{l}\text { Parking } \\
\text { Cost* }^{*}\end{array}$ & \multicolumn{5}{|c|}{$\begin{array}{l}\text { If the respondent reduced the number of cars because parking is insufficient or } \\
\text { expensive, } 1 \text {; else } 0\end{array}$} & $13.39 \%$ & 127 \\
\hline Car Cost* & \multicolumn{5}{|c|}{$\begin{array}{l}\text { If the respondent reduced the number of cars because car ownership is expensive, } 1 \text {; } \\
\text { else } 0\end{array}$} & $18.90 \%$ & 127 \\
\hline Life Event* & \multicolumn{5}{|c|}{$\begin{array}{l}\text { If the respondent reduced the number of cars because he/she moved or experienced } \\
\text { other life events (marriage, school, divorce, etc.), } 1 \text {; else } 0\end{array}$} & $12.60 \%$ & 127 \\
\hline Rare Use* & \multicolumn{5}{|c|}{$\begin{array}{l}\text { If the respondent reduced the number of cars because he/she rarely drives or he/she } \\
\text { has physical constraints, } 1 \text {; else } 0\end{array}$} & $27.56 \%$ & 127 \\
\hline $\begin{array}{l}\text { Old \& } \\
\text { Broken } \\
\text { Cars* }\end{array}$ & \multicolumn{5}{|c|}{$\begin{array}{l}\text { If the respondent reduced the number of cars because the car was old, broken, or } \\
\text { stolen, } 1 \text {; else } 0\end{array}$} & $25.20 \%$ & 127 \\
\hline
\end{tabular}

${ }^{*}$ denotes binary variables; TNC: Tranportation Network Company.

Table 3 presents the modeling outcomes for car ownership, and only three variables were significant. Income was the core measurement for car ownership. High-income people were more likely to have cars. People stated various reasons for driving. Faster speeds and traveling with children or carrying stuff were strong incentives for owning cars. The McFadden $\mathrm{R}^{2}$ value was 0.84 , indicating that the model had the very good predictive ability.

Despite continual claims that millennials favor multimodal transport and new, technology-based transport options, in this study, no significant evidence was found that differentiated millennials from prior generations. From our 
Table 2: Heckman Sample Selection Modeling Outcome for Car Reduction

\begin{tabular}{|c|c|c|}
\hline \multicolumn{3}{|c|}{ Probit Selection Equation: } \\
\hline & Estimate & P-Value \\
\hline Intercept & -0.781 & 0.075 \\
\hline Millennials & 0.166 & 0.448 \\
\hline Income & 0.001 & 0.185 \\
\hline Gender & -0.207 & 0.219 \\
\hline White & -0.345 & 0.096 \\
\hline Asian & $-0.731^{* *}$ & 0.004 \\
\hline In/Out SF & 0.094 & 0.588 \\
\hline Car Own & 0.191 & 0.644 \\
\hline Speed & $-0.470^{*}$ & 0.021 \\
\hline Trip Chain & 0.326 & 0.077 \\
\hline Loading or Children & 0.201 & 0.265 \\
\hline TNCUse & 0.037 & 0.649 \\
\hline \multicolumn{3}{|c|}{ Outcome Equation (Trip Frequency): } \\
\hline & Estimate & P-Value \\
\hline Intercept & $1.203^{*}$ & 0.042 \\
\hline Parking Cost & 0.279 & 0.450 \\
\hline Car Cost & 0.285 & 0.429 \\
\hline Life Event & -0.051 & 0.879 \\
\hline Rare Use & -0.208 & 0.495 \\
\hline Old or Broken Car & 0.023 & 0.942 \\
\hline \multicolumn{3}{|l|}{ Multiple $\mathrm{R}^{2}: 0.05$} \\
\hline \multicolumn{3}{|l|}{ Error terms: } \\
\hline & Estimate & P-Value \\
\hline Inverse Mills Ratio & 0.036 & 0.918 \\
\hline Sigma & 0.786 & NA \\
\hline Rho & 0.046 & NA \\
\hline
\end{tabular}

Level of Significance: ${ }^{(* * *)} 0.001,{ }^{(* *)} 0.01,{ }^{(*)} 0.05$

2-step Heckman estimation

325 observations ( 262 censored and 63 observed)

21 free parameters $(\mathrm{df}=305)$

perspective, the observation that millennials favor multimodal transport systems is based on temporal characteristics due to the great recession. The nationwide patterns of car reduction from 2010 to 2016 can largely be explained by economic conditions, while millennials' preferences may have only played a minor role.

This study included various attitudinal factors on an individual level. However, no attitudinal factor was significant in explaining car reduction, indicating that incentives for car reduction are random and diverse. People that are more concerned with ease of access and use were generally more likely to own cars. 
Table 3: Binary Logit Modeling Outcome on Car Ownership

\begin{tabular}{|l|r|r|}
\hline Binomial Logit Estimation & Estimate & P-Value \\
\hline Intercept & 0.147 & 0.865 \\
\hline Millennials & 0.488 & 0.521 \\
\hline Income & $0.012^{*}$ & 0.024 \\
\hline Gender & 0.749 & 0.212 \\
\hline White & 1.051 & 0.121 \\
\hline Asian & 0.933 & 0.219 \\
\hline In/Out SF & -1.013 & 0.105 \\
\hline Speed & $1.844^{* *}$ & 0.003 \\
\hline Trip Chain & 0.675 & 0.361 \\
\hline Loading or Children & $1.362^{*}$ & 0.047 \\
\hline TNC Use & -0.095 & 0.712 \\
\hline
\end{tabular}

Level of Significance: ${ }^{(* * *)} 0.001,{ }^{(* *)} 0.01,{ }^{(*)} 0.05$

Null deviance: 133.42 on 324 degrees of freedom

Residual deviance: 96.03 on 314 degrees of freedom

McFadden $\mathrm{R}^{2}: 0.84(\mathrm{df}=11)$

AIC: 118.03

These findings are inconsistent with prior studies. This study agrees that car ownership decreased over the past years. It is possible that prior studies overstated the preferences of millennials and created the impression that prior generations have less of an impact on car reduction. Furthermore, SF residents have the highest per capita income among all US citizens, especially with a concentration of young IT engineers with Silicon Valley. Although driving is expensive, as long as their earnings can cover transport costs, people will continue to drive. Lastly, the data were sampled in 2015, when the economy had almost recovered. In other words, some millennials had the money to afford a car, and they wanted to save on travel time.

\section{ACKNOWLEDGEMENTS}

This work was supported by the National Institute for Congestion Research (USDOT, OST-R). 


\section{REFERENCES}

Agresti, Alan. 2003. Categorical Data Analysis. John Wiley \& Sons. https://doi.org/10.1002/ $\underline{0471249688 .}$.

Circella, Giovanni, Farzad Alemi, Rosaria Berliner, Kate Tiedeman, Yongsung Lee, Lewis Fulton, Susan Handy, and Patricia L. Mokhtarian. 2017. "The Multimodal Behavior of Millennials: Exploring Differences in Travel Choices between Young Adults and Gen Xers in California." In 96th Transportation Research Board Annual Meeting.

Delbosc, Alexa, and Kelcie Ralph. 2017. "A Tale of Two Millennials." Journal of Transport and Land Use 10 (1): 903-10. https://doi.org/10.5198/jtlu.2017.1006.

Heckman, James. 1977. "Sample Selection Bias As a Specification Error (with an Application to the Estimation of Labor Supply Functions).” National Bureau of Economic Research. https://doi.org/ $\underline{10.3386 / \mathrm{w} 0172 .}$.

Heckman, James J. 1976. "The Common Structure of Statistical Models of Truncation, Sample Selection and Limited Dependent Variables and a Simple Estimator for Such Models." Annals of Economic and Social Measurement 5 (4).

McDonald, Noreen C. 2015. “Are Millennials Really the 'Go-Nowhere' Generation?” Journal of the American Planning Association 81 (2): 90-103. https://doi.org/10.1080/ $\underline{01944363.2015 .1057196 .}$.

Sivak, Michael. 2018. Has Motorization in the US Peaked? Part 10: Vehicle Ownership and Distance Driven, 1984 to 2016. Ann Arbor: The University of Michigan. 